\title{
How the migratory phenomenon is represented in the written press in Tenerife
}

Prepared by Daniel Buraschi and Inmaculada Fumero de León

The media, and their importance in defining the discourse that takes hold on society, are the guiding thread of this text that analyses, quantitatively and qualitatively, how news of migrants arriving in Tenerife is covered and framed. 


\section{Introduction: the media and immigration}

From our knowledge and understanding of how the migratory phenomenon is represented in the media, we can deduce key elements in relation to the opinions and attitudes of the citizenry regarding this phenomenon.

The media have the ability to focus the public's interest on certain issues in a way that is speculative and excludes certain events. The media's agenda, defined as the set of topics that are considered of interest, in turn influences the political and social agenda. That is: on the one hand, it guides the attention of the public, highlighting certain topics and excluding others; on the other, it determines how relevant a certain topic is.

For example, irregular migrations by sea, despite not being the main entry point for irregular immigration, represent one of the most recurrent themes in the media when talking about migratory phenomena (Igartua, Muñiz and Cheng, 2005; Van Dijk, 2016). This results in the intensity, volume and impact of maritime migrations being overemphasised in the public opinion.

In other words, we must take into account not only what is said, but also what is not said. The media can contribute to concealing the important role that migrants play in our society.

In addition to defining the relevant issues, the media always, explicitly or implicitly, frame the news in a certain way, meaning that the news conveys certain values, beliefs, and expectations that influence the recipients. Framing the news means focusing on a topic in a certain way; setting an agenda; selecting the key expressions that define the discourse; placing emphasis on some of these expressions; and defining a "central organising idea" to construct the narrative.

In this context, researchers define framing as the ability of the media to provoke certain conclusions in the audience, depending on how the information is presented. The same news events can be presented in different, and sometimes contradictory, ways. We can highlight the positive or the negative, show the active role of migrants or represent them through stereotypes and as a homogeneous and passive group; defining them on the basis of their otherness.

Studies carried out in Europe underscore how the media's representation of immigration is predominantly negative. The issues that stand out involve the problems of the migrants' legality, cultural differences (religious fundamentalism) and inter-ethnic relationships (Van Dijk, 2016). Studies conducted in Spain also highlight how immigration is generally framed in a negative light (Igartua, Muñiz and Cheng, 2005). In addition, there is little variety in the themes and a lack of contextualisation in this type of news, especially on television (Igartua and Muñiz, 2004).

In an analysis of news framing on immigration carried out by lgartua, Muñiz and Cheng (2005), the following dominant framings were identified: "irregular entry of immigrants in small boats", "actions involving immigrant minors", "immigrants live in pitiful conditions, are helpless and need help" or "immigrants as conflictive actors who cause incidents, riots, attacks and escapes". 
More recently, Fajardo Fernández and Soriano Miras (2016: 142) analysed the news published in six national and three regional newspapers and found that "migrants are portrayed in most cases as passive agents, as the victims of mafias or as the focus of the assistance services provided by various entities. In some news, they are portrayed as actors who use violence to achieve their purpose, while there are few cases in which they appear as an active subject not associated with conflict. In short, the dominant story 'decitizenises' these people in the various accounts analysed".

However, despite the general trend towards thematic framings that focus on irregular immigration and the link between immigration and social problems, we need to realise that research on this issue has highlighted how there are notable differences based on the ideological orientation of the newspaper, the immigrant community in question and the migratory and political context.

The dominant type of framing does not depend only on the ideological orientation of newspapers - there being notable differences between right- and left-wing newspapers there are also differences between national and local newspapers. For example, a study by Fernández and Corral (2016) found that regional newspapers emphasised aspects related to labour, culture and conviviality, while national newspapers published in Spain made more references to the conflicts generated.

In the Canary Islands, there are few systematic analyses of how immigration is covered in the press. The empirical studies focus primarily on the years of the cayuco crisis (20062008). Rodríguez Borges (2010) conducted an extensive study of the news published throughout 2006 in five Canarian newspapers (El Día, El Diario de Avisos, La Opinión, La Provincia and Canarias 7). An analysis of the thematic content of the selected articles shows that the management of irregular migratory flows (arrivals, detentions, transfers and repatriations) and the controversies between political parties and institutions prevailed in $79.2 \%$ of the news stories on immigration.

Ardoval Abreu (2008) has studied how immigration was portrayed in the photographs of four Canarian newspapers (El Día, El Diario de Avisos, La Provincia and Canarias 7) over the course of 2007. The results of his study show that the media represent only some aspects of the migratory phenomenon: immigration is almost exclusively associated with the arrival of small boats from Africa, and the immigrant portrayed is almost exclusively "sub-Saharan" or Moroccan, prioritising the stereotypical group image instead of one that seeks out individuality and difference. In addition, the study emphasises how the photographic representation usually identifies Africans with weakness, lack of initiative and subordination. It also associates them with crime, while ignoring other, more numerous groups like Latin Americans. 


\section{The main issues involving immigration in the Tenerife press}

As part of an extensive study on how immigration and conviviality are perceived in Tenerife, the Tenerife Immigration Observatory analysed the thematic framings in a sample of 698 headlines and their corresponding standfirsts. The sample spans all those articles related to the migratory phenomenon published in the on-line editions of the three main local newspapers in Tenerife (El Día, Diario de Avisos and La Opinión) over three years (2016-2018).

These three newspapers have a strong presence and significance on the island of Tenerife. All of them have been considerably affected by the financial crisis since 2007, which has resulted in notable corporate vulnerabilities that have given rise to various changes, ranging from sales to national groups to, in the case of La Opinión, the disappearance of the newspaper.

The first aspect worth noting involving the media's coverage of immigration in Tenerife is that in the last three years, immigration has not been a central issue in the island's press, especially when compared to the levels of media attention it garnered a decade ago. In 2006, the three leading newspapers published 6,057 news stories on immigration (Rodríguez Borges, 2010), while in the last three years, this number dropped significantly: 242 in 2016, 98 in 2017 and 358 in 2018.

It should be pointed out that in 2016, 32,000 immigrants arrived on board 588 small boats, irregular immigration by sea to the Canary Islands became a matter of European importance and, for the first time, the opinion barometer of the CIS (Centre for Sociological Research) showed that immigration was the leading concern for Spaniards

Figure 1 (CIS, study 2654). The monthly distribution in the number of news stories on immigration

Monthly distribution of news stories involving immigration in the three leading newspapers (2016-2018).

Source OBITen Intergroup Perception Project 2017-2019. over the last three years shows that there have been four upswings: the first involved the European debate related to the "Syrian refugee crisis", while the other three began with the extensive media coverage of the arrival of Aquarius in Spain, and involve the reactivation of the "Western Route", referring to the increased number of immigrants who have reached Spain irregularly by sea.

The Aquarius is a ship used by the NGO SOS Méditerraneé for rescue missions. In June 2018, the vessel, with more than 600 people on board, was on the high seas after Italy and Malta prohibited it from docking at their ports. On June 11, the Spanish Government offered to receive the immigrants at the port of Valencia.

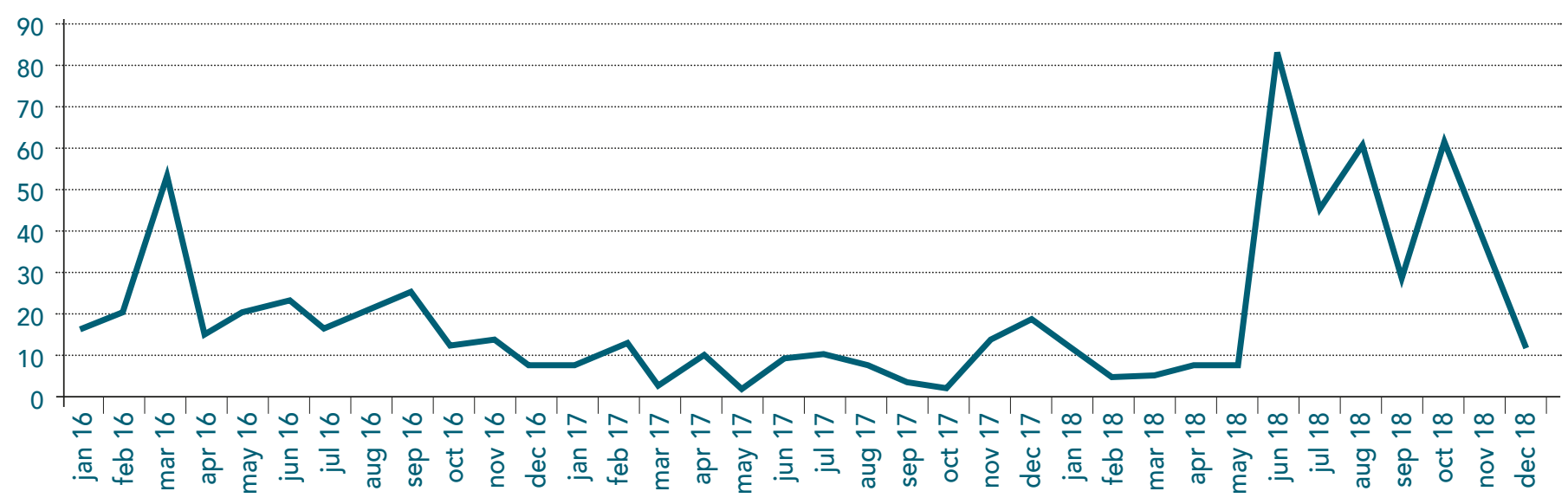


As concerns the main topics covered in the news, irregular immigration is, by far, the main issue. This is followed by news on migration policies, which are also practically entirely related to irregular immigration. The volume of monthly news stories on irregular arrivals is not proportional to the number of people or vessels actually arriving in the Archipelago; rather, it increases when the debate at the national level intensifies. That is to say, it is the national debate that defines the media's agenda on immigration, rather than the local migratory reality, although this trend may change if the number of irregular arrivals by sea in the Canary Islands increases.

In $2018,38.5 \%$ of the news stories referred to immigration in the islands, $32.7 \%$ to immigration in Spain, $14.0 \%$ to the rest of Europe and $14.8 \%$ to the rest of the world. As Rodrígez Borges (2010:21) pointed out ten years ago, "regarding the thematic content of news on immigration, the behaviour of Canarian newspapers, unfortunately, mirrors that of the national press. Although, fortunately, the link between immigration and crime is barely noticeable".

\begin{tabular}{l|c|c|c|c|}
\hline \multicolumn{1}{|c|}{ News topics } & $\mathbf{2 0 1 6}$ & $\mathbf{2 0 1 7}$ & $\mathbf{2 0 1 8}$ & Total \\
\hline Irregular immigration & 31.4 & 39.8 & 51.1 & 42.7 \\
\hline Migration and integration policies & 14.9 & 14.3 & 20.1 & 17.5 \\
\hline Solidarity and defence of migrants' rights & 17.8 & 22.4 & 5.0 & 11.9 \\
\hline $\begin{array}{l}\text { Reception of refugees and unaccompanied } \\
\text { foreign minors }\end{array}$ & 13.6 & 2.0 & 9.2 & 9.7 \\
\hline Other & 12.0 & 6.1 & 6.7 & 8.6 \\
\hline Immigration analysis and data & 7.9 & 12.2 & 5.6 & 7.3 \\
\hline Immigration as a problem & 2.1 & 3.1 & 2.2 & 2.3 \\
\hline Total & 100 & 100 & 100 & 100 \\
\hline
\end{tabular}

Table 1

Distribution of news stories by topic and year (\%).

Source

OBITen Intergroup Perception Project 2017-2019.

Except for irregular arrivals or stays, the link between immigration and crimes or other negative effects on Canarian society is minimal. In contrast, the non-mention of multiple issues related to immigration is striking (conviviality, Latin American and European immigration, positive contributions of immigration to society, etc.).

\section{Security, neutral and supportive approaches}

An important aspect in understanding the media's coverage of immigration is the type of framing used to present the news. In studies on migration and the media, it is common to speak of security, neutral and supportive framings. The security framing emphasises issues related to security: crime, presenting immigration as a problem, arrests of irregular immigrants, the management of Immigrant Detention Centres, etc. The supportive framing, on the other hand, includes news that highlights solidarity, the defence of migrants' rights, social projects involving shelters and conviviality. As for the neutral framing, it groups news stories that reflect demographic changes, rescues of migrants and the analysis of the migratory phenomenon, without adding a positive or negative bias. 


\section{Factsheet OBITen_03}

As the Figure 2 shows, the dominant framing in the Tenerife press is neutral. This is mainly due to the types of sources used to discuss the main subject matter: currently, when it comes to irregular immigration, the press in Tenerife usually reproduces the information disseminated by institutions, namely, the rescue operations involving migrants carried out and reported by Maritime Rescue.

Figure 2

Distribution of news by type of framing (\%)

Source

OBITen Intergroup Perception Project 2017-2019.

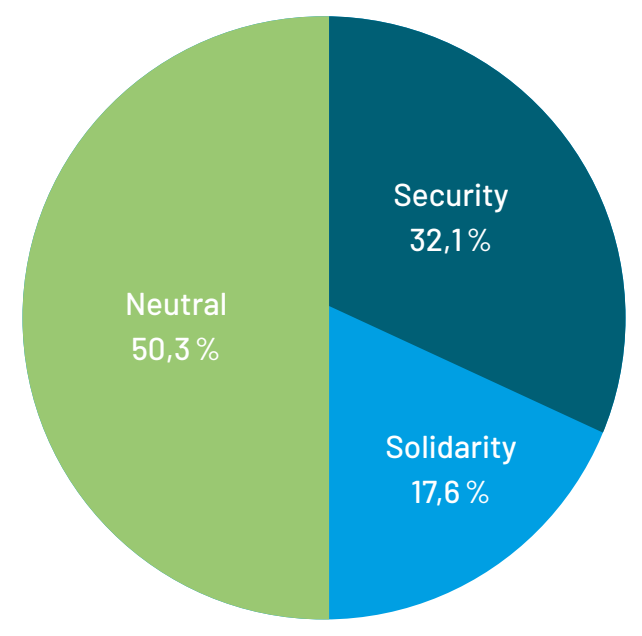

The difference between 2016 and 2018 in terms of the supportive and security approaches is striking: in 2016, the theme at the centre of the media agenda was the "Syrian refugee crisis", which had a very limited impact in Spain, and none in the Canary Islands, and irregular immigration in other countries. That year saw the publication of 61 "supportive" news stories. In 2018, as more irregular migrants arrived in Spain by sea, the supportive coverage decreased, with the consequent rise in stories framed from a security perspective. In other words: the supportive framing is featured in the media when the immigrants are far away, and it shifts when immigrants arrive on our shores.
Figure 3

Distribution of public news stories by framing and year.

Source OBITen Intergroup Perception Project 2017-2019.

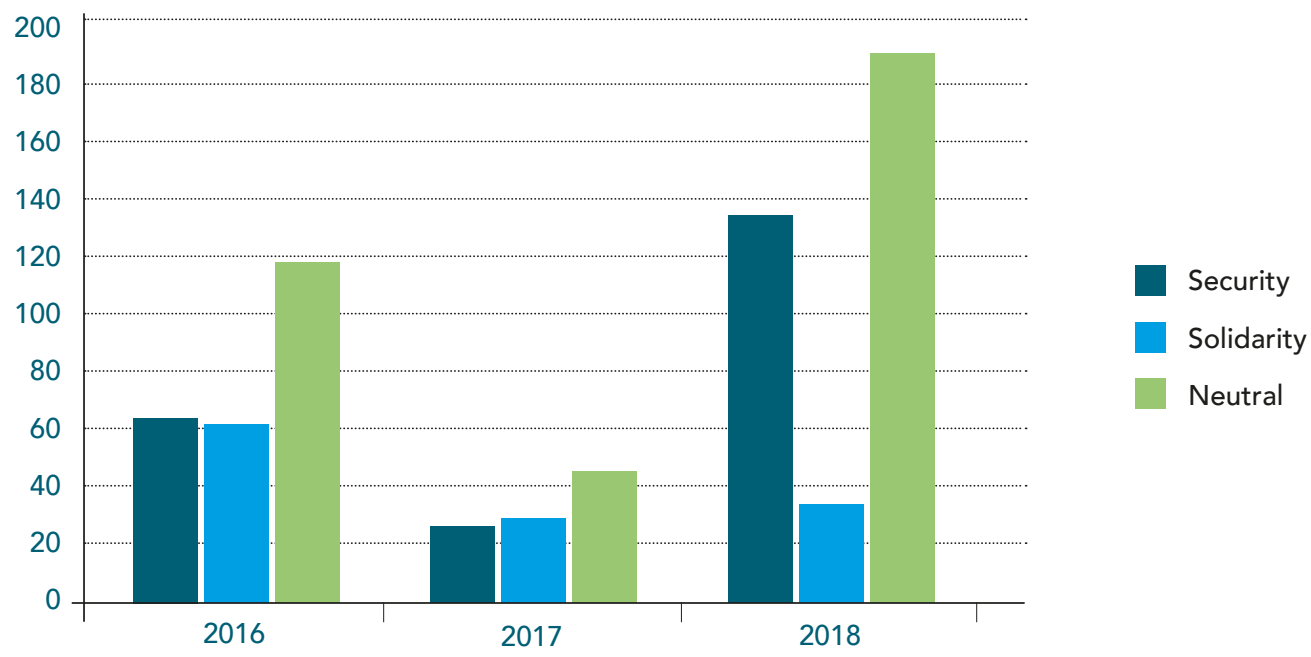




\section{Origins and types of immigrants featured in the news}

The migration phenomenon in Tenerife is not homogeneous; rather, it varies considerably by place and time. For example, the most notable aspect of the migratory movements currently affecting Tenerife is the significant increase in people of Venezuelan and Italian origin. However, the press continues to overrepresent, as it did a decade ago, a specific immigrant profile: African in an irregular administrative status.

In the last three years, immigrants of African origin have played the starring role in news on immigration, although there are significant differences between 2016 and 2018 . In 2016, the main news stories involved the refugee crisis and, together with people of African origin, many news items made references to people of Asian origin, almost entirely to people of Syrian origin.

\begin{tabular}{l|c|c|c|c|}
\hline \multicolumn{1}{c|}{ Origin } & $\mathbf{2 0 1 6}$ & $\mathbf{2 0 1 7}$ & $\mathbf{2 0 1 8}$ & Total \\
\hline Africa & 38.0 & 54,1 & 70.9 & 57.2 \\
\hline America & 0.8 & 3.1 & 7.8 & 4.7 \\
\hline Asia & 37.2 & 6.1 & 5.3 & 16.5 \\
\hline Europe & 0.0 & 5.1 & 0.3 & 0.9 \\
\hline Canary Islands & 2.5 & 1.0 & 0.8 & 1.4 \\
\hline Not specified & 21.5 & 30.6 & 14.8 & 19.1 \\
\hline Total & $\mathbf{1 0 0 . 0}$ & $\mathbf{1 0 0 . 0}$ & $\mathbf{1 0 0 . 0}$ & $\mathbf{1 0 0 . 0}$ \\
\hline
\end{tabular}

Table 2

Distribution of headlines by origin of the group featured in the news and year (\%).

Source

OBITen Intergroup Perception Project 2017-2019.

If we analyse the headlines by the "type of immigration", the change between the years is even more striking: in 2016 the focus was primarily on refugees or asylum seekers, while in 2017 and 2018, the news on refugees decreased significantly, replaced by those involving irregular immigrants, which would account for two-thirds of all the news stories published in 2018. Also notable in this case is that when people speak of refugees, they speak almost exclusively of people of Syrian origin, when in Spain, and especially in the Canary Islands, the country of origin with the highest number of applicants $(10,350$ in Spain) was Venezuela.

\begin{tabular}{l|c|c|c|c|}
\hline \multicolumn{1}{r|}{ Type of immigrant } & 2016 & 2017 & $\mathbf{2 0 1 8}$ & Total \\
\hline Immigrants in general & 9.5 & 27.6 & 14.8 & 14.8 \\
\hline Foreign workers & 5.4 & 7.1 & 1.7 & 3.7 \\
\hline Unaccompanied foreign minors & 3.7 & 1.0 & 7.8 & 5.4 \\
\hline Irregular immigrants & 35.5 & 56.1 & 67.9 & 55.0 \\
\hline Refugees & 40.5 & 6.1 & 5.0 & 17.5 \\
\hline Victims of sexual exploitation & 0.0 & 1.0 & 0.3 & 0.3 \\
\hline Criminals & 2.5 & 0.0 & 1.4 & 1.6 \\
\hline Canarian immigrants and emigrants & 2.5 & 1.0 & 0.8 & 1.4 \\
\hline Others & 0.4 & 0.0 & 0.3 & 0.3 \\
\hline Total & 100.0 & 100.0 & 100.0 & 100.0 \\
\hline
\end{tabular}

Table 3

Distribution of headlines by type of immigration and year (\%).

\section{Source}

OBITen Intergroup Perception Project 2017-2019. 
Another aspect of note is that the voice of migrants has been practically absent from news published in the last three years. The institutions and the parties comprise the main sources for the news, while migrants provided the source material for only seven of the 698 news stories analysed, that is, $1 \%$. This deafness to the voice of migrants has been evidenced by numerous studies (Van Dijk, 2016; Igartua, Muñiz and Cheng, 2005; Rodríguez Borges, 2010; Fajardo Fernández and Soriano Miras, 2016) and, unfortunately, it is a mainstay at the European, national and local levels.

\section{In conclusion}

In the last three years, the media have not devoted the same attention to immigration as they did a decade ago, although in the wake of the Aquarius story and the reactivation of the Western Route, the number of published news articles has increased significantly. Issues related to maritime borders and the irregular entry of immigrants feature prominently in newspapers published in Tenerife. This thematic framing includes news on the arrival of small boats, the arrest of boat captains, the rescue of immigrants by Maritime Rescue and the death of immigrants as they attempt to reach the islands by sea. A particularly important aspect to understanding the prototypical image that Canarian society can have of immigrants is that, if we consider the groups of immigrants that are featured in news articles, two-thirds of them focus on those who are in the country illegally. These data show how irregular maritime migrations in 2016, 2017 and 2018, despite being far from representing a numerically significant phenomenon, were at the centre of the media agenda when talking about migration in the Canary Islands.

The news published in the Tenerife press generally adopts a neutral framing that is primarily associated with institutional sources of information. Headlines rarely explicitly relate migration to social problems, and in comparison to the 2006-2007 period, flagrantly xenophobic and racist opinion articles and editorials have all but disappeared. However, it must be borne in mind that throughout 2018, with respect to 2016, the number of news stories with a supportive framing decreased significantly (more related to the Syrian refugee crisis), and the number of news with a security framing increased. 


\section{For more information:}

Ardévol Abreu, A. (2008). La inmigración, en la fotografía de prensa de Canarias. Revista Latina de Comunicación Social, 11(63), 409-417.

Fajardo Fernández, R. and Soriano Miras, R. M. (2016). La construcción mediática de la migración en el Mediterráneo: ¿no-ciudadanía en la prensa española?. Revista Internacional de Estudios Migratorios, 6(1), 141-169.

Fernández, C. and Corral, A. (2016). La representación mediática del inmigrante magrebí en España durante la crisis económica (2010-2011). Migraciones internacionales, 8(4), 73-103.

Igartua J. J. and Muñiz, C. (2004). Encuadres noticiosos e inmigración. Un análisis de contenido de la prensa y televisión españolas. Zer. Revista de Estudios de Comunicación, 16, 87-104.

Igartua, J. J., Muñiz, C. and Cheng, L. (2005). La inmigración en la prensa española. Aportaciones empíricas y metodológicas desde la teoría del encuadre noticioso. Migraciones, 17, 143-181.

Rodríguez Borges, R. F. (2010). El tratamiento informativo de la inmigración en la prensa de Canarias. Fuentes, temas y enfoques dominantes. Boletín Millares Carlo, (29), 307-330.

Van Dijk, T. A. (2016). Estudios Críticos del Discurso: Un enfoque sociocognitivo. Discurso \& Sociedad, 1, 137-162.

\section{How to cite this article:}

Buraschi, D. and Fumero de León, I. (2019). How the migratory phenomenon is represented in the written press in Tenerife. OBITen Factsheet 3-2019. Taken from www.obiten.net.

https://doi.org/10.25145/r.obitfact.2019.09

The Tenerife Immigration Observatory is a joint initiative of the Tenerife Council and the University of La Laguna that is intended to provide a permanent and dynamic structure to advance our scientific knowledge of migratory movements. The OBITen carries out its activity by gathering, producing and disseminating knowledge to facilitate qualified opinions and promote the making of decisions that help to better manage migratory phenomena and their implications.

http://www.obiten.net 